\title{
Exposure to Environmental Tobacco Smoke in Relation to Behavioral, Emotional, Social and Health Indicators of Slovak School Children
}

\author{
Ludmila Sevcikova ${ }^{1}$, Jana Babjakova ${ }^{1}$, Jana Jurkovicova ${ }^{1}$, Martin Samohyl ${ }^{1}$, \\ Zuzana Stefanikova ${ }^{1}$, Erika Machacova ${ }^{2}$, Diana Vondrova ${ }^{1}$, Etela Janekova ${ }^{1,3}$, \\ Katarina Hirosova ${ }^{1}$, Alexandra Filova ${ }^{1}$, Michael Weitzman ${ }^{1,4}$ and Lubica Argalasova ${ }^{1, *}$ \\ 1 Institute of Hygiene, Faculty of Medicine, Comenius University, Bratislava, 813 72, Slovakia; \\ ludmila.sevcikova@fmed.uniba.sk (L.S.); jana.babjakova@fmed.uniba.sk (J.B.); \\ jana.jurkovicova@fmed.uniba.sk (J.J.); martin.samohyl@fmed.uniba.sk (M.S.); \\ zuzana.stefanikova@fmed.uniba.sk (Z.S.); diana.vondrova@fmed.uniba.sk (D.V.); janekova@inclinic.sk (E.J.); \\ katarina.hirosova@fmed.uniba.sk (K.H.); alex.filova@gmail.com (A.F.); \\ Michael.Weitzman@NYUMC.ORG (M.W.) \\ 2 Institute of Epidemiology, Faculty of Medicine, Comenius University, Bratislava, 813 72, Slovakia; \\ erika.machacova@fmed.uniba.sk \\ 3 InClinic s.r.o, Bratislava, 851 01, Slovakia \\ 4 Department of Pediatrics, New York University, New York, NY, 10016, USA \\ * Correspondence: lubica.argalasova@fmed.uniba.sk
}

Received: 5 May 2018; Accepted: 26 June 2018; Published: 30 June 2018

\begin{abstract}
Environmental tobacco smoke (ETS) exposure has been shown in general as a major environmental risk factor and deserves attention in vulnerable population groups. The aim of the project is to analyze the relationships among the ETS and behavior and health in 6-15-year-old children in Slovakia. The status of physical and mental health of children in relation to exposure to tobacco smoke was examined in a representative group of 1478 school children. The methods used, included anonymous questionnaires filled in by parents, Columbia Impairment Scale (CIS), Behavior Problem Index (BPI) and anthropometry. The prevalence of ETS exposure is the highest in the capital $(27 \%)$ and southern cities. A significant association was found between ETS and age, socio-economic status, incompleteness of the family, level of mother's education and a higher prevalence of respiratory diseases $(26.7 \%)$. The relationships of ETS with emotional (CIS scores $\geq 16$ ) and behavioral functions (BPI score $\geq 14$ ) were significant in children exposed to mother's or father's smoking at home. In the multivariate analysis these associations were not significant; the factors such as income and completeness of the family were dominant. The results showed mostly the predominant impact of social factors on the physical and mental health status of Slovak school children.
\end{abstract}

Keywords: Environmental Tobacco Smoke (ETS); Slovak school children; mental health; physical health; Columbia Impairment Scale; Behavioral Problem Index

\section{Introduction}

Numerous national and international studies and health reports provide evidence of the adverse impact of Environmental Tobacco Smoke (ETS) on health during the last decades [1-7]. ETS, also known as passive cigarette smoke, is linked with premature deaths and many physical and mental disorders [8-11]. 
The use of the term secondhand smoke (SHS) as a synonym for ETS is not appropriate in light of recent studies. These studies demonstrate that ETS is composed not only of SHS but also of Third Hand Smoke (THS). Third hand smoke is a complex phenomenon resulting from residual tobacco smoke pollutants that adhere to the clothing and hair of smokers and to surfaces, furnishings, and dust in indoor environments. Exposure can even take place long after smoking has ceased, through close contact with smokers and in indoor environments in which tobacco is regularly smoked [12-15]. Exposure to ETS may cause lung cancer, eye, nose, and throat irritation, may affect the cardiovascular system and may cause stroke [16-19]. ETS is a serious factor in indoor air pollution, which has an influence on health of predominantly vulnerable population groups-children of all ages $[4,9,20-22]$ and pregnant women living in the same house as a habitual cigarette smoker $[4,10]$. Effects include sudden infant death syndrome (SIDS), asthma, bronchitis and pneumonia, and other respiratory diseases, and an adverse effect on the developing fetus. ETS exposure negatively affects birth outcomes, especially birth weight and behavior disorders [23-25]. The associations among ETS exposure during the prenatal or postnatal period and behavioral, emotional problems and mental health in childhood and adolescence have become the subject of many studies [7,26-29]. Even children whose mothers had prenatal ETS exposure in any one or more of the pregnancy trimesters were more likely to exhibit hyperactivity behaviors as compared with those born to non-exposed mothers [30].

More than a third of all people are regularly exposed to the harmful effects of smoke. This exposure is responsible for about 600,000 deaths per year, and about $1 \%$ of the global burden of disease worldwide [31]. In 2004, 40\% of children were exposed to ETS in public places worldwide [18]. According to the 2007 Global Youth Tobacco Survey (GYTS), more than 50\% of children in Slovakia between the ages of 13-15 were exposed to ETS [32].

The aim of the present study is to analyze the relationships among the ETS exposure and emotional and behavioral problems and health in 6-15 year old children in Slovakia.

\section{Material and Methods}

The status of physical and mental health of children in relation to exposure to tobacco smoke in the family was examined in 1478 school children aged 6-15 years, equal number of boys and girls. The representative group was sampled by random selection of schools in each participating district from regions of the east, middle and western part of Slovakia, of which pupils were randomly selected into Stage I (first to fourth grade) or Stage II (fifth to ninth grade). Of the 2023 questionnaires distributed to the parents of selected grades in 11 primary schools from all over Slovakia 73\% (1478) were returned and processed, ranging from 43 to $93 \%$ in different schools and localities. Details about the study sample are presented in the previous article of Sevcikova et al. [33]. The study was performed in October and November, 2009. Standard methods (questions based on widely utilized questionnaires) for evaluation of the smoking and socio-economic status of family, environmental conditions, children's regimens, their health status and anthropometric variables (height, weight) were used. The parents, after informed consent, were given written instructions to fill out the anonymous questionnaires at home and to return it to the teacher via children. This included questions regarding family and child demographic and socioeconomic characteristics, child gender and age, and ETS exposure in the home as determined by whether either the mother or the father reported that they smoked cigarettes at home. Demographic information included family income, ethnicity, maternal and paternal educational attainment, and town/city versus village residence. We set a threshold of $600 €$ according to the average net money income of private households in Slovakia by the year 2008 [34]. BMI-for-age-gender percentile was used for evaluation of overweight/obesity (the criterion for overweight and obesity was set at the 90th and 97th P of the national standards from 2001) [35].

Emotional and behavioral functions of children were assessed using validated questionnaires: The Columbia Impairment Scale (CIS) and The Behavior Problem Index (BPI). CIS is a tool for emotional problems screening by 13 structured questions having fixed response options, with scores ranging from 0 to 52 and tap four major areas of functioning as: (1) interpersonal relations, (2) 
broad psychopathological domains (e.g., anxiety, depression or behavior problems); (3) functioning in job or school and (4) use of leisure time. When an item is not applicable (e.g., problems getting along with siblings for an only child), or missing, the mean of all scored items for that individual was assigned as that item score. A score of 16 or higher is considered clinically impaired [36-38]. The BPI has 25 questions with scores ranging from 0 to 25 (how much of a problem with antisocial behavior, cheating, disobedience at home, at school, bullying or cruel behavior, anxious/depressed behavior, headstrongness, short temper, irritability, sensitivity, nervousness, hyperactivity, difficulty concentrating, impulsive thinking, restlessness, conflicting behavior or social isolation, social immaturity). A score of 14 or above indicates behavior problems [33,39].

Surveys were included if they were missing fewer than five responses. For included surveys with missing data, the data was imputed by replacing the missing values from blank responses with the average of all the other questions.

The association between maternal and paternal smoking in the household and emotional and behavioral problems (CIS $\geq 16$ ) and (BPI $\geq 14$ ), and other child, maternal, and family characteristics were examined in bivariate analyses using chi-square tests and crude odds ratios with $95 \%$ confidence intervals. The age (6-10 or 11-15 years), gender, residence (town or country), income ( $\leq 600 €$ or $>600 €)$ were investigated as well as basic life style habits and anthropometric characteristics (BMI) in relation to ETS exposure in the household. The most important questions on CIS and BPI were analyzed separately in bivariate analysis with household smoking. Multivariate analyses were performed to identify those factors independently associated with increased scores, indicative of child emotional and behavioral problems, for all of these variables using adjusted odds ratios. All analyses were conducted in SAS (SAS Institute, Cary, NC, USA and SPSS 25 (International Business Machines Corp.; New Orchard Road; Armonk, New York, USA) programs. The statistically significant level was determined at $p$ values $<0.05$.

The project was approved by Ethical Committee Faculty of Medicine, Comenius University Bratislava, Slovakia and by Institutional Review Board of New York University School of Medicine, New York, U.S.A (IRB number: 09-0331).

\section{Results}

The prevalence of ETS in Slovak children (mother or father reported smoking at home) was 19\% (Table 1). It was significantly the highest in the capital (27.6\%) and southern border cities (24-27\%) [33]. The characteristics of smoking with social status of families are presented in Table 1.

Significant relationships between ETS and the level of mother's and father's education, father's employment, socio-economic status and completeness of the family were found in bivariate analysis (Table 2). The older school children were more exposed to ETS, but not significantly. Exposure to ETS decreased with the level of parental education-especially the mother. The relationships with socio-economic status and incompleteness of the family have been shown, as well as the marginally significant higher frequency of respiratory system diseases (bronchitis, pneumonia) during the last year in children exposed to ETS $(p=0.04)$. Children exposed to ETS have worse eating habits and regimen, watch TV and play games longer during the day. The relationship between ETS and lower physical activity and sports was statistically significant. The exposure to ETS also was associated with a significantly increased prevalence of overweight/obesity in this sample of Slovak children $(p=0.01)$ (Table 2).

There were $4.6 \%$ boys and $2.5 \%$ girls in our sample who were active smokers. These children were exposed to ETS in the family (boys- $88 \%$, girls— $94 \%$ ). They were excluded from further analyses with the final sample being 1373 non-smoking children. 
Table 1. Characteristics of the sample of Slovak children $(n=1478)$.

\begin{tabular}{|c|c|c|}
\hline Indicator * & $n$ & $\%$ \\
\hline \multicolumn{3}{|l|}{ Age group (years) } \\
\hline $6-10$ & 953 & 64.8 \\
\hline 11-15 & 517 & 35.2 \\
\hline \multicolumn{3}{|l|}{ Gender } \\
\hline Boys & 738 & 50.6 \\
\hline Girls & 720 & 49.4 \\
\hline \multicolumn{3}{|l|}{ Mother education } \\
\hline Primary & 51 & 3.5 \\
\hline High school & 360 & 24.6 \\
\hline High school completed & 739 & 50.6 \\
\hline University & 311 & 21.3 \\
\hline \multicolumn{3}{|l|}{ Mother smokes } \\
\hline Yes & 309 & 21.3 \\
\hline No (ex-smoker) & 114 & 7.9 \\
\hline No & 1025 & 70.8 \\
\hline \multicolumn{3}{|l|}{ Father education } \\
\hline Primary & 41 & 2.9 \\
\hline High school & 566 & 40.4 \\
\hline High school completed & 505 & 36.1 \\
\hline University & 289 & 20.6 \\
\hline \multicolumn{3}{|l|}{ Father smokes } \\
\hline Yes & 484 & 36.5 \\
\hline No (ex-smoker) & 161 & 12.2 \\
\hline No & 680 & 51.3 \\
\hline \multicolumn{3}{|l|}{ The child smokes } \\
\hline Yes, more times & 22 & 1.54 \\
\hline Yes, one time & 30 & 2.11 \\
\hline No, never & 1373 & 96.35 \\
\hline \multicolumn{3}{|l|}{ Mother or father smokes } \\
\hline Yes & 610 & 41.16 \\
\hline No & 872 & 58.84 \\
\hline \multicolumn{3}{|c|}{ Mother or father smokes at home } \\
\hline Yes & 278 & 18.8 \\
\hline No & 1204 & 81.2 \\
\hline \multicolumn{3}{|l|}{ The child lives in the } \\
\hline Uncomplete family & 287 & 19.62 \\
\hline Complete family & 1176 & 80.38 \\
\hline \multicolumn{3}{|l|}{ Monthly household income } \\
\hline$\leq 400 €$ & 146 & 11.6 \\
\hline $401-600 €$ & 233 & 18.6 \\
\hline$>600 €$ & 877 & 69.8 \\
\hline \multicolumn{3}{|l|}{ Number of siblings } \\
\hline 0 & 289 & 20.2 \\
\hline $1-2$ & 949 & 66.3 \\
\hline$\geq 3$ & 194 & 13.5 \\
\hline \multicolumn{3}{|l|}{ Residence } \\
\hline Urban & 1169 & 81.01 \\
\hline Rural & 274 & 18.99 \\
\hline
\end{tabular}

* There are some data missing in each variable category. 
Table 2. Relations between selected indicators and children's exposure to ETS $(n=1373)$ *.

\begin{tabular}{|c|c|c|c|}
\hline Indicator $* *$ & $\begin{array}{c}\text { Exposure ETS - } \\
(\%)\end{array}$ & $\begin{array}{c}\text { Exposure ETS + } \\
(\%)\end{array}$ & $p$-Value \\
\hline \multicolumn{4}{|l|}{ Age (years) } \\
\hline $6-10$ & 82.3 & 17.7 & \multirow[t]{2}{*}{0.08} \\
\hline $11-15$ & 78.3 & 21.7 & \\
\hline \multicolumn{4}{|l|}{ Mother education } \\
\hline Primary & 51.2 & 48.8 & \multirow{4}{*}{$<0.0001 * * *$} \\
\hline High school & 73.5 & 26.5 & \\
\hline High school completed & 82.5 & 17.5 & \\
\hline University & 89.7 & 10.3 & \\
\hline \multicolumn{4}{|l|}{ Father education } \\
\hline Primary & 52.6 & 47.4 & \multirow{4}{*}{$<0.0001^{* * *}$} \\
\hline High school & 75.3 & 24.7 & \\
\hline High school completed & 83.3 & 16.7 & \\
\hline University & 92.5 & 7.5 & \\
\hline \multicolumn{4}{|l|}{ Father employment } \\
\hline Unemployed & 54.5 & 45.5 & \multirow[t]{2}{*}{$<0.0001 * * *$} \\
\hline Employed & 81.7 & 18.3 & \\
\hline \multicolumn{4}{|l|}{ Monthly household income } \\
\hline$\leq 400 €$ & 60.9 & 39.1 & \multirow{3}{*}{$<0.0001 * * *$} \\
\hline $401-600 €$ & 70.2 & 29.8 & \\
\hline$>600 €$ & 85.4 & 14.6 & \\
\hline \multicolumn{4}{|l|}{ Completeness of the family } \\
\hline No & 69 & 31 & \multirow[t]{2}{*}{$<0.0001 * * *$} \\
\hline Yes & 83.7 & 16.3 & \\
\hline \multicolumn{4}{|l|}{ Respiratory system diseases } \\
\hline No & 81.7 & 18.3 & \multirow{2}{*}{$=0.04 *$} \\
\hline Yes & 73.6 & 26.4 & \\
\hline \multicolumn{4}{|l|}{$\begin{array}{l}\text { Child eating healthy (vegetable, } \\
\text { fruits, number of portions) }\end{array}$} \\
\hline Yes & 82.6 & 17.4 & \multirow[t]{2}{*}{$0.03 *$} \\
\hline No & 77.8 & 21.1 & \\
\hline \multicolumn{4}{|l|}{ Child doing sports } \\
\hline No sports, rarely & 72.9 & 27.7 & \multirow{3}{*}{$0.04 *$} \\
\hline Recreationally, 1-2 times a week & 80.8 & 19.2 & \\
\hline Regularly more time a week/daily & 82.5 & 17.5 & \\
\hline \multicolumn{4}{|l|}{ TV/Games combined } \\
\hline$\leq 2 \mathrm{~h}$ daily & 84.3 & 15.7 & \multirow[t]{2}{*}{$<0.0001 * * *$} \\
\hline$>2 \mathrm{~h}$ daily & 66.1 & 33.9 & \\
\hline \multicolumn{4}{|l|}{ Overweight/Obesity } \\
\hline No & 82.3 & 17.7 & \multirow[t]{2}{*}{$=0.01 *$} \\
\hline Yes & 75.58 & 24.42 & \\
\hline
\end{tabular}

* $\overline{\text { ETS }=\text { mother or father smokes at home; }{ }^{* *} \text { There are some data missing in each variable category; }{ }^{*} p<0.05 ;{ }^{* * *} p<0.001}$.

The relationships between environmental tobacco smoke exposure (father or mother smoking at home) with disorders of emotional and behavioral functions (CIS scores $\geq 16$ and BPI scores $\geq 14$ ) were significant in bivariate analysis (ORcrude, CIS $\geq 16=1.76$ (95\% CI = 1.00-3.14; ORcrude, BPI $\geq 14$ ) $=1.66(95 \%$ CI $=1.07-2.60)$ (Table 3$)$.

The association of a smoking mother (at home or elsewhere) with child emotional problems (CIS) was significant as demonstrated in Table 4. 
Table 3. Relations between behavioral functions (BPI) and emotional functions (CIS) and the exposure of children to father's or mother's smoking at home $(n=1373)$ (bivariate analysis).

\begin{tabular}{cccccc}
\hline \multirow{2}{*}{ Indicator } & \multirow{2}{*}{ Exposure ETS (\%) } & \multicolumn{4}{c}{ Risk Estimation } \\
\cline { 3 - 6 } & & OR (Crude) & $\mathbf{9 5 \%} \mathbf{C I}$ & Chi-Square & $p$-Value \\
\hline CIS score $\geq \mathbf{1 6}$ & 6.67 & 1.76 & $1.00-3.14$ & 4.37 & $\mathbf{0 . 0 5} *$ \\
BPI score $\geq \mathbf{1 4}$ & 11.72 & 1.66 & $1.07-2.60$ & 5.19 & $\mathbf{0 . 0 2}$ \\
\hline
\end{tabular}

Table 4. Relations between emotional functions (CSI) and behavioral functions (BPI) and the exposure of children to mother's smoking ${ }^{\dagger}(n=1373)$ (bivariate analysis).

\begin{tabular}{cccccc}
\hline \multirow{2}{*}{ Indicator } & \multirow{2}{*}{ Exposure ETS (\%) } & \multicolumn{4}{c}{ Risk Estimation } \\
\cline { 3 - 6 } & & OR (Crude) & $\mathbf{9 5 \%} \mathbf{C I}$ & Chi-Square & $p$-Value \\
\hline CIS score $\geq \mathbf{1 6}$ & 8.05 & 2.13 & $1.10-4.11$ & 5.30 & $\mathbf{0 . 0 2}$ \\
BPI score $\geq \mathbf{1 4}$ & 11.72 & 1.53 & $0.89-2.66$ & 2.37 & 0.12 \\
\hline \multicolumn{5}{c}{$*<<0.05 ;{ }^{+}$mother smokes elsewhere. }
\end{tabular}

In the analysis of individual behavioral and emotional characteristics of the child in relation to mother's smoking the association with antisocial behavior of children, anxiety, depressed mood were found to be statistically significant in bivariate analysis (Table 5). The importance of the mother's influence on some behavioral characteristics (BPI) of school children has been shown. The association of mother's smoking with individual emotional characteristics of the child (CIS) was not significant.

Table 5. Behavioral characteristics of children (BPI) and mother's smoking ${ }^{\dagger}$ ( $\left.n=1373\right)$ (bivariate analysis).

\begin{tabular}{|c|c|c|c|c|c|}
\hline \multirow{2}{*}{ Behavioral Characteristics of Children } & \multirow{2}{*}{ Exposure ETS (\%) } & \multicolumn{4}{|c|}{ Risk Estimation } \\
\hline & & OR (Crude) & $95 \%$ CI & Chi-Square & $p$-Value \\
\hline \multicolumn{6}{|c|}{ Antisocial behavior of children } \\
\hline She/he cheats or tells lies & 33.69 & 1.31 & $1.00-1.74$ & 3.57 & $0.05 *$ \\
\hline She/he is disobedient at school & 22.97 & 1.50 & $1.07-2.05$ & 5.90 & 0.015 * \\
\hline She/he hangs around with kids who get into trouble & 21.43 & 1.27 & $0.92-1.75$ & 2.02 & 0.15 \\
\hline \multicolumn{6}{|c|}{ Anxiety and depressed mood } \\
\hline She/he has sudden changes in mood or feelings & 25.00 & 1.27 & $0.93-1.72$ & 2.27 & 0.13 \\
\hline She/he feels or complains that no one loves him/her & 22.26 & 1.67 & $1.20-2.31$ & 9.36 & $0.002 *$ \\
\hline
\end{tabular}

In contrast, social factors (income and completeness of the family) were statistically significant in multivariate analyses among factors independently associated with children's behavioral (BPI) and emotional (CIS) problems. The exposure to ETS at home (mother or father smoking at home) was not significant in relation to disorders of emotional functions (CIS) and behavioral functions (BPI) in multivariate analysis (Tables 6 and 7).

Table 6. Factors associated with Children's Behavioral Problems (BPI $\geq 14$ ) among Children in Multivariate Analyses $(n=1373)^{\dagger}$.

\begin{tabular}{ccc}
\hline & Adjusted OR & $\mathbf{9 5 \%} \mathbf{C I}$ \\
\hline ETS & 1.0245 & $0.58-1.81$ \\
Yes & 1 & - \\
No & 1 & - \\
Age & 0.73 & $0.43-1.24$ \\
6-10 years & & \\
$11-15$ years & 1 & - \\
Gender & 0.60 & $0.37-0.96$ \\
Male & &
\end{tabular}


Table 6. Cont.

\begin{tabular}{|c|c|c|}
\hline & Adjusted OR & $95 \%$ CI \\
\hline \multicolumn{3}{|l|}{ Residence } \\
\hline Urban & 1 & - \\
\hline Rural & 1.57 & $0.89-2.75$ \\
\hline \multicolumn{3}{|l|}{ Maternal education } \\
\hline Primary + Some high school & 1.08 & $0.62-1.87$ \\
\hline High school diploma + University & 1 & - \\
\hline \multicolumn{3}{|l|}{ Paternal education } \\
\hline Primary + Some high school & 1.38 & $0.83-2.29$ \\
\hline High school diploma + University & 1 & - \\
\hline \multicolumn{3}{|l|}{ Income } \\
\hline$\leq 600 €$ & 1.95 & $1.11-3.44$ * \\
\hline$>600 €$ & 1 & - \\
\hline \multicolumn{3}{|l|}{ Completeness of the family } \\
\hline No & 1.91 & $1.02-3.55$ * \\
\hline Yes & 1 & - \\
\hline
\end{tabular}

${ }^{+}$There are some missing data in each variable category; ${ }^{*} p<0.05$.

Table 7. Factors associated with Children's Emotional Problems (CSI $\geq 16)$ among Children in Multivariate Analyses $(n=1373)^{\dagger}$.

\begin{tabular}{|c|c|c|}
\hline & Adjusted OR & $95 \% \mathrm{CI}$ \\
\hline \multicolumn{3}{|l|}{ ETS } \\
\hline Yes & 1.25 & $0.57-2.72$ \\
\hline No & 1 & - \\
\hline \multicolumn{3}{|l|}{ Age } \\
\hline $6-10$ years & 1 & - \\
\hline $11-15$ years & 2.05 & $1.06-3.94 *$ \\
\hline \multicolumn{3}{|l|}{ Gender } \\
\hline Male & 1 & - \\
\hline Female & 0.64 & $0.35-1.26$ \\
\hline \multicolumn{3}{|l|}{ Residence } \\
\hline Urban & 1 & - \\
\hline Rural & 1.44 & $0.65-3.18$ \\
\hline \multicolumn{3}{|l|}{ Maternal education } \\
\hline Primary + Some high school & 0.54 & $0.22-1.32$ \\
\hline High school diploma + University & 1 & \\
\hline \multicolumn{3}{|l|}{ Paternal education } \\
\hline Primary + Some high school & 0.51 & $0.24-1.07$ \\
\hline High school diploma + University & 1 & - \\
\hline \multicolumn{3}{|l|}{ Income } \\
\hline$\leq 600 €$ & 2.31 & $0.93-4.75 *$ \\
\hline$>600 €$ & 1 & - \\
\hline \multicolumn{3}{|l|}{ Completeness of the family } \\
\hline No & 3.54 & $1.58-7.94 * *$ \\
\hline Yes & 1 & - \\
\hline
\end{tabular}

\section{Discussion}

The analysis of the exposure of Slovak school children to ETS revealed a high number of smoking parents $(21 \%$ of mothers and $37 \%$ of fathers). There were $8 \%$ of ex-smokers among mothers and $12 \%$ among fathers. The results showed that $19 \%$ of children are exposed to ETS in the household. The significant differences among regions were revealed with the highest numbers of exposed children in the capital (Bratislava) and the cities in the south of Slovakia. 
The first data on household ETS exposure of Slovak school children are from 1996 in the framework of the Central European Study on Air Pollution and Respiratory Health (CESAR) study on a sample of $25317-11$ year old children. That study demonstrated the very high prevalence of ETS exposure- $48.4 \%$ children [40].

Slovakia belongs to the countries with a relatively high prevalence of smoking. The WHO Report on the Global Tobacco Epidemic presented the age and sex standardized adult daily smoking prevalence in 2009 in Slovakia as 29\% (38\% men and 19\% women) [6]. Comparable national data of Tobacco and Health Education Survey in 2014 showed the same prevalence 29\%, but with the higher percentage in women-24\% and lower in men-34\% [41]. The prevalence of smoking parents in our study was $21 \%$ of smoking mothers and $37 \%$ of smoking fathers.

The home is the primary source of ETS exposure for infants and children and a major source of ETS exposure for non-smoking adults, mostly mothers [10,42-44]. In our study the older children were more exposed to ETS, however not significantly. Children of parents with lower education (especially mothers) are significantly more exposed to ETS. Many prior studies have found lower maternal education and poverty to be associated with child ETS exposure [45-48].

Children exposed to ETS were significantly more often ill, e.g., for respiratory system diseases. Many studies have reported adverse effects of prenatal and/or postnatal exposure on children's respiratory health $[18,49]$. Among children whose mothers smoke, the risk of asthma is higher. A child with asthma is twice as likely to end up in the hospital if family members smoke [50]. Children exposed to ETS have an increased risk of developing lung cancer in adulthood, even if they never smoked [51]. These serious consequences from exposure to tobacco smoke for children's respiratory health urgently needs to be reduced.

Children whose parents smoke and children from low-SES families are still most likely to be exposed to tobacco smoke [52]. The known relationships of ETS exposure with socio-economic status and incompleteness of the family $[6,18]$ also have been confirmed in our study.

Children exposed to ETS have worse living habits, worse nutrition, less sport activities, and watch more TV and are more likely to play computer games. Results demonstrate more sedentary daily activities in the exposed children. These negative habits in exposed children may be influenced also by lower socioeconomic status or education of a smoking mother $[53,54]$.

Slovak school children exposed to ETS tend to be overweight and obese similar to those in the US [55].

The significant association between ETS exposure and mental health has been found in many studies $[38,56]$. Numerous potential pathways have been proposed, including alterations in brain functions or structure due to exposure to nicotine or to the other chemicals in exhaled tobacco smoke [29]. The potential social, genetic and behavioral confounders (e.g., psychological stress, maternal depression, and family functioning), as well as potential causal neurobiological pathways (e.g., dopamine system) remain as potential contributors [11].

Children living with smokers are at increased risk for emotional or behavioral problems [38]. The associations among developmental, neurocognitive or behavioral problems in children and tobacco exposure may have substantial effects on functioning and quality of life and also other risks, in which genetic and societal factors have an essential impact [55,57-60]. Mental and physical load in school children could be associated also with the educational process [61], that we did not study in this sample. The exposure to environmental tobacco smoke, even at extremely low levels, is associated with decreases in certain cognitive skills in children and adolescents [62]. Both animal model and human epidemiologic data clearly suggest a causal relationship between prenatal tobacco exposure and adverse behavioral and neurocognitive effects on children [63]. Many studies described the association between prenatal tobacco or postnatal ETS exposure and the following adverse behavioral and emotional outcomes: conduct disorder, attention-deficit/hyperactivity disorder, poor academic achievement, and cognitive impairment [59,63-65]. 
Children exposed to ETS in the present study scored higher (worse) in emotional and behavioral problems (score CIS and BPI) only in bivariate analysis. The more bivariate analysis of individual behavioral and emotional characteristics performed in this study also revealed associations with ETS exposure in the households. However, the exposure to ETS was not significant in relation to disorders of emotional functions (CIS scores $\geq 16$ ) and behavioral functions (BPI score $\geq 14$ ) in multivariate analysis in the current as well as in the previous study [33]. The social factors (income and completeness of the family) were dominant, eliminating the statistical significance found in bivariate analysis. Further neurobiological research to establish causal pathways is needed $[11,66]$.

Results of this study also confirm that smoking of parents or other adult members of the family are significantly associated with active smoking in children. There were $4.6 \%$ boys and $2.5 \%$ girls in our sample with smoking experiences and they were exposed to passive smoking in the family as well (boys-88\%, girls-94\%). The causal relationship between environmental tobacco exposure and adverse behavioral and cognitive outcomes is suggested in many studies [55,59,64].

Children living in incomplete families or families earning less than the average income had increased rates of behavioral and emotional problems in multivariate analyses. This analysis also confirmed the relation of emotional problems with the age of children which may be related to puberty and adolescence. The number of children exposed to household smoking significantly differs in different Slovak regions; the highest prevalence was in the capital and the south of Slovakia. These areas need particular attention to anti-smoking interventions.

Our results confirm that, children exposed to ETS tend to be from lower socioeconomic families. Negative attitude toward smoking alongside knowledge of the effects of ETS are very important in interventions for decisions to maintain a smoke-free home [67].

The strength of this study is the representative sample of Slovak school children. Standardized and internationally accepted measures also were used (BPI, CIS-behavioral and emotional functions). Voluntary participation may represent some limitation by omission of "smoking" families. More accurate estimate of ETS exposure in children may have resulted if the evaluation of a biomarker were used. Cotinine levels in urine may provide tangible and objective evidence for ETS [68]. The effects of other potential environmental toxins on children also have not been investigated. Biomarkers of tobacco exposure help to clarify the role tobacco chemicals play in influencing health both in childhood and beyond [69].

The results showed mostly the predominant impact of social factors on health status and health behaviors of Slovak school children lowering the apparent impact of ETS. Nevertheless, ETS is an important public health problem in Slovakia and should lead to further research on ETS interactions with social factors on physical and mental health of children and parents as well. They are important for application in clinical practice and public policy.

\section{Conclusions}

The results showed the predominant role of social factors on health status and health behaviors of Slovak school children, eliminating the association of ETS with these domains found in crude (bivariate) analysis. Nevertheless, ETS is an important public health problem in Slovakia and should lead to further research on ETS interactions with social factors on physical and mental health of children and parents as well.

The exposure to ETS has been documented as a risk factor in children with lower education of parents (especially mothers), lower socio-economic status of the family and incompleteness of the family.

The significant relationship between negative dietary habits, lower exercise, longer TV watching, overweight and the ETS exposure has been confirmed as in other studies. Our study revealed a lack of intervention in the area of the children's protection from exposure to toxic tobacco smoke. In Slovakia more public health activities in children protection from tobacco smoke in the family and household smoking bans are urgently needed. It is necessary to continue systematically and more vigorously in 
activities that lead to secure children's rights to protection against smoking, which started in Slovakia in the year 2000. Education concentrated on family and society and systematic preventive health-care during childhood and adolescence belong to fundamental aspects of public health policy. An important role is played by the education of all population groups and an intensive campaign against the risk to children's health caused by ETS exposure.

Author Contributions: L.S., L.A., M.W. conceived and designed the project, L.S., L.A. wrote the manuscript, L.A., J.B., A.F. analysed the data, J.J. provided critical revision of the manuscript, M.S., D.V., K.H., Z.S., E.M., E.J. performed literature search and drafted sections of the manuscript, M.W. did the language, style and spell check. All authors have approved the submitted version.

Funding: This manuscript was partially supported by the grant Y.A.B.S. (Youth and Parents Behavioral Survey in Slovakia) O-15-101-/0001-00, by the ESFOPV project, MPH study programme development at Comenius University in Bratislava in English language (Master of Public Health) ITMS code of the project: 261402300093 and by KEGA project No 057UK-4/2017 Innovation of teaching by multimedia training program creation for the health protection and promotion of population.

Acknowledgments: We thank the staff of Pediatric Department Faculty of Medicine Comenius University in Bratislava; collaborators from Regional Public Health Institutes in Bratislava, Komarno, Cadca, Nitra, Nove Zamky, Prievidza, Stara Lubovna, Vranov nad Toplou, Ziar nad Hronom helping us with performance of the project.

Conflicts of Interest: The authors declare no conflict of interest.

\section{References}

1. Aligne, C.A.; Moss, M.E.; Auinger, P.; Weitzman, M. Association of pediatric dental caries with passive smoking. JAMA 2003, 289, 1258-1264. [CrossRef] [PubMed]

2. Pirkle, J.L.; Bernert, J.T.; Caudill, S.P.; Sosnoff, C.S.; Pechacek, T.F. Trends in the Exposure of Nonsmokers in the US Population to Secondhand Smoke: 1988-2002. Environ. Health Perspect. 2006, 114, 853-858. [CrossRef] [PubMed]

3. Moritsugu, K.P. The 2006 Report of the Surgeon General: The health consequences of involuntary exposure to tobacco smoke. Am. J. Prev. Med. 2007, 32, 542-543. [CrossRef] [PubMed]

4. Wipfli, H.; Avila-Tang, E.; Navas-Acien, A.; Kim, S.; Onicescu, G.; Yuan, J.; Breysse, P.; Samet, J.M.; Famri Homes Study Investigators. Secondhand smoke exposure among women and children: Evidence from 31 countries. Am. J. Public Health 2008, 98, 672-679. [CrossRef] [PubMed]

5. World Health Organization. WHO Report on the Global Tobacco Epidemic, 2009: Implementing Smoke-Free Environments; WHO: Geneva, Switzerland, 2009.

6. World Health Organization. WHO Report on the Global Tobacco Epidemic, 2011: Warning about the Dangers of Tobacco; WHO: Geneva, Switzerland, 2011.

7. Bandiera, F.C.; Richardson, A.K.; Lee, D.J.; He, J.P.; Merikangas, K.R. Secondhand smoke exposure and mental health among children and adolescents. Arch. Pediatr. Adolesc. Med. 2011, 165, 332-338. [CrossRef] [PubMed]

8. DiFranza, J.R.; Aligne, C.A.; Weitzman, M. Prenatal and postnatal environmental tobacco smoke exposure and children's health. Pediatrics 2004, 113, 1007-1015. [PubMed]

9. Feleszko, W.; Ruszczyński, M.; Jaworska, J.; Strzelak, A.; Zalewski, B.M.; Kulus, M. Environmental tobacco smoke exposure and risk of allergic sensitisation in children: A systematic review and meta-analysis. Arch. Dis. Child. 2014, 99, 985-992. [CrossRef] [PubMed]

10. Sobotova, L.; Liu, Y.H.; Burakoff, A.; Sevcikova, L.; Weitzman, M. Household exposure to secondhand smoke is associated with decreased physical and mental health of mothers in the USA. Matern. Child Health J. 2011, 15, 128-137. [CrossRef] [PubMed]

11. Bandiera, F.C. What are candidate biobehavioral mechanisms underlying the association between secondhand smoke exposure and mental health? Med. Hypotheses 2011, 77, 1009-1010. [CrossRef] [PubMed]

12. Protano, C.; Vitali, M. The New Danger of Thirdhand Smoke: Why Passive Smoking Does Not Stop at Secondhand Smoke. Environ. Health Perspect. 2011, 119, a422. [CrossRef] [PubMed]

13. Protano, C.; Andreoli, R.; Manini, P.; Vitali, M. How home-smoking habits affect children: A cross-sectional study using urinary cotinine measurement in Italy. Int. J. Public Health 2012, 57, 885-892. [CrossRef] [PubMed] 
14. Matt, G.E.; Quintana, P.J.E.; Destaillats, H.; Gundel, L.A.; Sleiman, M.; Singer, B.C.; Jacob, P.; Benowitz, N.; Winickoff, J.P.; Rehan, V.; et al. Thirdhand tobacco smoke: Emerging evidence and arguments for a multidisciplinary research agenda. Environ. Health Perspect. 2011, 119, 1218-1226. [CrossRef] [PubMed]

15. Protano, C.; Andreoli, R.; Manini, P.; Guidotti, M.; Vitali, M. A tobacco-related carcinogen: Assessing the impact of smoking behaviours of cohabitants on benzene exposure in children. Tob. Control 2012, 21, 325-329. [CrossRef] [PubMed]

16. Centers for Disease Control and Prevention. Tobacco Information and Prevention Source (TIPS): Secondhand Smoke. 2004. Available online: http:/ / www.cdc.gov/tobacco/factsheets/secondhand_smoke_factsheet.htm (accessed on 25 July 2005).

17. Besaratinia, A.; Pfeifer, G.P. Second-hand smoke and human lung cancer. Lancet Oncol. 2008, 9, $657-666$. [CrossRef]

18. Oberg, M.; Jaakkola, M.S.; Woodward, A.; Peruga, A.; Prüss-Ustün, A. Worldwide burden of disease from exposure to second-hand smoke: A retrospective analysis of data from 192 countries. Lancet 2011, 377, 139-146. [CrossRef]

19. World Health Organization. Tobacco. Fact Sheet. 2018. Available online: http://www.who.int/mediacentre/ factsheets/fs339/en/ (accessed on 23 March 2018).

20. Office on Smoking and Health (US). Children and Secondhand Smoke Exposure. Excerpts from The Health Consequences of Involuntary Exposure to Tobacco Smoke: A Report of the Surgeon General; Centers for Disease Control and Prevention (US): Atlanta, GA, USA, 2007.

21. Kukla, L.; Hrubá, D.; Tyrlík, M. Influence of prenatal and postnatal exposure to passive smoking on infants' health during the first six months of their life. Cent. Eur. J. Public Health 2004, 12, 157-160. [PubMed]

22. World Health Organization. Tobacco-Free Initiative. 2005. Available online: www.who.int/tobacco/about/ en (accessed on 7 May 2008).

23. Nigg, J.T.; Breslau, N. Prenatal smoking exposure, low birth weight, and disruptive behavior disorders. J. Am. Acad. Child Adolesc. Psychiatry 2007, 46, 362-369. [CrossRef] [PubMed]

24. Pogodina, C.; Brunner Huber, L.R.; Racine, E.F.; Platonova, E. Smoke-free homes for smoke-free babies: The role of residential environmental tobacco smoke on low birth weight. J. Community Health 2009, 38, 376-382. [CrossRef] [PubMed]

25. Hrubá, D.; Kachlík, P. The influence of maternal active and passive smoking during pregnancy on birth weight in newborns. Cent. Eur. J. Public Health 2000, 8, 249-252. [PubMed]

26. Rückinger, S.; Rzehak, P.; Chen, C.M.; Sausenthaler, S.; Koletzko, S.; Bauer, C.P.; Hoffmann, U.; Kramer, U.; Berdel, D.; von Berg, A.; et al. Prenatal and postnatal tobacco exposure and behavioral problems in 10-year-old children: Results from the GINI-plus prospective birth cohort study. Environ. Health Perspect. 2010, 118, 150-154. [CrossRef] [PubMed]

27. Ashford, J.; van Lier, P.A.; Timmermans, M.; Cuijpers, P.; Koot, H.M. Prenatal smoking and internalizing and externalizing problems in children studied from childhood to late adolescence. J. Am. Acad. Child Adolesc. Psychiatry 2008, 47, 779-787. [CrossRef] [PubMed]

28. Boutwell, B.; Beaver, K. Maternal cigarette smoking during pregnancy and offspring externalizing behavioral problems: A propensity score matching analysis. Int. J. Environ. Res. Public Health 2010, 7, 146-163. [CrossRef] [PubMed]

29. Rosenthal, D.G.; Weitzman, M. Examining the effects of intrauterine and postnatal exposure to tobacco smoke on childhood cognitive and behavioral development. Int. J. Ment. Health 2014, 40, 39-64. [CrossRef]

30. Lin, Q.; Hou, X.Y.; Yin, X.N.; Wen, G.M.; Sun, D.; Xian, D.X.; Fan, L.; Jiang, H.; Jing, J.; Jin, Y.; et al. Prenatal Exposure to Environmental Tobacco Smoke and Hyperactivity Behavior in Chinese Young Children. Int. J. Environ. Res. Public Health 2017, 14, 1132. [CrossRef] [PubMed]

31. World Health Organization. Global Health Observatory Data. Second Hand Smoke. 2017. Available online: http://www.who.int/gho/phe/secondhand_smoke/en/ (accessed on 23 March 2018).

32. Baska, T.; Sovinova, H.; Nemeth, A.; Prewozniak, K.; Warren, C.W.; Baskova, M.; Czech Republic, Hungary, Poland and Slovakia GYTS Collaborative Group. Environmental tobacco smoke of youngsters in Czech Republic, Hungary, Poland and Slovakia-Findings from the Global Youth Tobacco Survey (GYTS). Int. J. Public Health 2007, 52, 62-66. [CrossRef] [PubMed] 
33. Sevcikova, L.; Slobodyanuk, K.; Argalasova, L.; Jurkovicova, J.; Stefanikova, Z.; Treitl, D.; Liu, Y.H.; Weitzman, M. Maternal smoking and child behavior in Slovakia. Int. J. Ment. Health 2011, 40, 92-103. [CrossRef]

34. Statistical Office of the Slovak Republic. Statistical Yearbook of the Slovak Republic. 2008. Available online: https:/ / spu.fem.uniag.sk/cvicenia/ksov/obtulovic/Hospodarska\%20statistika/SR2008/PUB/sk2008.pdf (accessed on 7 May 2018).

35. Ševčíková, L'; Nováková, J.; Hamade, J.; Tatara, M.; Janechová, H. Physical Development of Children and Adolescents in Slovakia Results of the VI-th National Survey in the Year of 2001; Public Health Authority of the Slovak Republic: Bratislava, Slovak, 2004.

36. Bird, H.R.; Shaffer, D.; Fisher, P.; Gould, M.; Staghezza, B. The Columbia Impairment Scale (CIS): Pilot findings on a measure of global impairment for children and adolescents. Int. J. Methods Psychiatr. Res. 1993, 3, 161-176.

37. Bird, H.R.; Andrews, H.; Schwab-Stone, M.; Goodman, S.; Dulcan, M.; Richters, J.; Rubio-Stipec, M.; Moore, R.E.; Chiang, P.H.; Hoven, C.H.; et al. Global measures of impairment for epidemiologic and clinical use with children and adolescents. Int. J. Methods Psychiatr. Res. 1996, 6, 295-307. [CrossRef]

38. Poole-Di Salvo, E.; Ying-Hua, L.; Brenner, S.; Weitzman, M. Adult household smoking is associated with increased child emotional and behavioral problems. J. Dev. Behav. Pediatr. 2010, 31, 107-115. [CrossRef] [PubMed]

39. Weitzman, M.; Gortmaker, S.; Sobol, A. Maternal smoking and behavior problems of children. Pediatrics 1992, 90, 342-349. [CrossRef] [PubMed]

40. Pattenden, S.; Antova, T.; Neuberger, M.; Nikiforov, B.; De Sario, M.; Grize, L.; Heinrich, J.; Hruba, F.; Janssen, N.; Luttmann-Gibson, H.; et al. Parental smoking and children's respiratory health: Independent effects of prenatal and postnatal exposure. Tob. Control 2006, 15, 294-301. [CrossRef] [PubMed]

41. World Health Organization. WHO Report on the Global Tobacco Epidemic, 2017: Monitoring Tobacco Use and Prevention Policies; WHO: Geneva, Switzerland, 2017.

42. Bloch, M.; Althabe, F.; Onyamboko, M.; Kaseba-Sata, C.; Castilla, E.E.; Freire, S.; Garces, A.L.; Parida, S.; Goudar, S.S.; Kadir, M.M.; et al. Tobacco use and secondhand smoke exposure during pregnancy: An investigative survey of women in 9 developing nations. Am. J. Public Health 2008, 98, 1833-1840. [CrossRef] [PubMed]

43. Argalášová, L'.; Ševčíková, L'.; Jurkovičová, J.; Babjaková, J.; Janeková, E.; Totka, A.; Šimko, M.; Weitzman, M. Determinants of ETS exposure in a sample of Slovak pregnant women. Rev. Environ. Health 2017, 32, 201-205. [CrossRef] [PubMed]

44. Milcarz, K.; Bak-Romaniszyn, L.; Kaleta, D. Environmental Tobacco Smoke Exposure and Smoke-Free Rules in Homes among Socially-Disadvantaged Populations in Poland. Int. J. Environ. Res. Public Health 2017, 14, 447. [CrossRef] [PubMed]

45. Martinez, F.D.; Cline, M.; Burrows, B. Increased incidence of asthma in children of smoking mothers. Pediatrics 1992, 89, 21-26. [PubMed]

46. Schuster, M.A.; Franke, T.; Pham, C.B. Smoking patterns of household members and visitors in homes with children in the United States. Arch. Pediatr. Adolesc. Med. 2002, 156, 1094-1100. [CrossRef] [PubMed]

47. King, K.; Martynenko, M.; Bergman, M.; Liu, Y.; Winickoff, J.; Weitzman, M. Family composition and children's exposure to adult smokers in their homes. Pediatrics 2009, 123, e559-e564. [CrossRef] [PubMed]

48. Hawkins, S.S.; Berkman, L. Identifying infants at high-risk for second-hand smoke exposure. Child Care Health Dev. 2014, 40, 441-445. [CrossRef] [PubMed]

49. Janson, C.; Chinn, S.; Jarvis, D.; Zock, J.P.; Torén, K.; Burney, P. Effect of passive smoking on respiratory symptoms, bronchial responsiveness, lung function, and total serum $\operatorname{IgE}$ in the European Community Respiratory Health Survey: A cross-sectional study. Lancet 2001, 358, 2103-2109. [CrossRef]

50. Pyle, R.C.; Divekar, R.; May, S.M.; Narla, N.; Pianosi, P.T.; Hartz, M.F.; Ott, N.L.; Park, M.A.; McWilliams, D.B.; Green, J.A.; et al. Asthma-associated comorbidities in children with and without secondhand smoke exposure. Ann. Allergy Asthma Immunol. 2015, 115, 205-210. [CrossRef] [PubMed]

51. Olivo-Marston, S.E.; Yang, P.; Mechanic, L.E.; Bowman, E.D.; Pine, S.R.; Loffredo, C.A.; Alberg, A.J.; Caporaso, N.; Shields, P.G.; Chanock, S.; et al. Childhood exposure to secondhand smoke and functional mannose binding lectin polymorphisms are associated with increased lung cancer risk. Cancer Epidemiol. Biomark. Prev. 2009, 18, 3375-3383. [CrossRef] [PubMed] 
52. Kuntz, B.; Lampert, T. Social disparities in parental smoking and young children's exposure to secondhand smoke at home: A time-trend analysis of repeated cross-sectional data from the German KiGGS study between 2003-2006 and 2009-2012. BMC Public Health 2016, 16, 485. [CrossRef] [PubMed]

53. Rogers, I.; Emmett, P. The effect of maternal smoking status, educational level and age on food and nutrient intakes in preschool children: Results from the Avon longitudinal study of parents and children. Eur. J. Clin. Nutr. 2003, 57, 854-864. [CrossRef] [PubMed]

54. Cutler-Triggs, C.; Fryer, G.E.; Miyoshi, T.J.; Weitzman, M. Increased rates and severity of child and adult food insecurity in households with adult smokers. Arch. Pediatr. Adolesc. Med. 2008, 162, 1056-1062. [CrossRef] [PubMed]

55. Weitzman, M.; Cook, S.; Auinger, P.; Florin, T.A.; Daniels, S.; Nguyen, M.; Winickoff, J.P. Tobacco smoke exposure is associated with the metabolic syndrome in adolescents. Circulation 2005, 112, 862-869. [CrossRef] [PubMed]

56. Hook, B.; Cederblad, M.; Berg, R. Prenatal and postnatal maternal smoking as risk factors for preschool children's mental health. Acta Paediatr. 2006, 95, 671-677. [CrossRef] [PubMed]

57. Wakschlag, L.S.; Pickett, K.E.; Cook, E., Jr.; Benowitz, N.L.; Leventhal, B.L. Maternal smoking during pregnancy and severe antisocial behaviour in offspring: A review. Am. J. Public Health 2002, 92, 966-974. [CrossRef] [PubMed]

58. Pachter, L.M.; Auinger, P.; Palmer, R.; Weitzman, M. Do parenting and the home environment, maternal depression, neighborhood, and chronic poverty affect child behavioral problems differently in different racial-ethnic groups? Pediatrics 2006, 117, 1329-1338. [CrossRef] [PubMed]

59. Herrmann, M.; King, K.; Weitzman, M. Prenatal tobacco smoke and postnatal secondhand smoke exposure and child neurodevelopment. Curr. Opin. Pediatr. 2008, 20, 184-190. [CrossRef] [PubMed]

60. Twardella, D.; Bolte, G.; Fromme, H.; Wildner, M.; von Kries, R. GME Study Group. Exposure to secondhand tobacco smoke and child behavior-Results from a cross-sectional study among preschool children in Bavaria. Acta Paediatr. 2010, 99, 106-111. [CrossRef] [PubMed]

61. Vondrova, D.; Kapsdorfer, D.; Argalasova, L.; Hirosova, K.; Samohyl, M.; Sevcikova, L. The impact of selected environmental, behavioral and psychosocial factors on schoolchildren's somatic and mental health. Rev. Environ. Health 2017, 32, 189-192. [CrossRef] [PubMed]

62. Cincinnati Children's Hospital Medical Center. Environmental Tobacco Smoke Linked to Behavior Problems in Children and Pre-Teens. 2006. Available online: www.sciencedaily.com/releases/2006/04/060430225821. htm (accessed on 30 April 2006).

63. Weitzman, M.; Byrd, R.S.; Aligne, C.A.; Moss, M. The effects of tobacco exposure on children's behavioral and cognitive functioning: Implications for clinical and public health policy and future research. Neurotoxicol. Teratol. 2002, 24, 397-406. [CrossRef]

64. Zhou, S.; Rosenthal, D.G.; Sherman, S.; Zelikoff, J.; Gordon, T.; Weitzman, M. Physical, behavioral, and cognitive effects of prenatal tobacco and postnatal secondhand smoke exposure. Curr. Probl. Pediatr. Adolesc. Health Care 2014, 44, 219-241. [CrossRef] [PubMed]

65. Hamer, M.; Ford, T.; Stamatakis, E.; Dockray, S.; Batty, G.D. Objectively measured secondhand smoke exposure and mental health in children: Evidence from the Scottish health survey. Arch. Pediatr. Adolesc. Med. 2011, 165, 326-331. [CrossRef] [PubMed]

66. Yousey, Y.K. Household characteristics, smoking bans, and passive smoke exposure in young children. J. Pediatr. Health Care 2006, 20, 98-105. [CrossRef] [PubMed]

67. Huang, K.; Chen, H.; Liao, J.; Nong, G.; Yang, L.; Winickoff, J.P.; Zhang, Z.; Abdullah, A.S. Factors Associated with Complete Home Smoking Ban among Chinese Parents of Young Children. Int. J. Environ. Res. Public Health 2016, 13, 161. [CrossRef] [PubMed]

68. Boyaci, H.; Etiler, N.; Duman, C.; Basyigit, I.; Pala, A. Environmental tobacco smoke exposure in school children: Parent report and urine cotinine measures. Pediatr. Int. 2006, 48, 382-389. [CrossRef] [PubMed]

69. Peterson, L.A.; Hecht, S.S. Tobacco, E-Cigarettes and Child Health. Curr. Opin. Pediatr. 2017, $29,225-230$. [CrossRef] [PubMed]

(C) 2018 by the authors. Licensee MDPI, Basel, Switzerland. This article is an open access article distributed under the terms and conditions of the Creative Commons Attribution (CC BY) license (http://creativecommons.org/licenses/by/4.0/). 